\title{
Covid-19: Spatial analysis of lethality in France during the first epidemic inception
}

Marc Souris and Jean-Paul Gonzalez

\section{(2) OpenEdition \\ 1 Journals}

Electronic version

URL: http://journals.openedition.org/rfst/901

DOI: $10.4000 /$ rfst.901

ISSN: 2492-3672

Publisher

Espaces et SOciétés (UMR 6590)

\section{Electronic reference}

Marc Souris and Jean-Paul Gonzalez, "Covid-19: Spatial analysis of lethality in France during the first epidemic inception", Revue francophone sur la santé et les territoires [Online], Pandemic, crises and perspectives: territorial readings of Covid-19, Online since 11 March 2021, connection on 06 April 2021. URL: http://journals.openedition.org/rfst/901 ; DOI: https://doi.org/10.4000/rfst.901

This text was automatically generated on 6 April 2021.

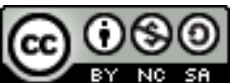

La Revue francophone sur la santé et les territoires est mise à disposition selon les termes de la Licence Creative Commons Attribution - Pas d'Utilisation Commerciale - Partage dans les Mêmes Conditions 4.0 International. 


\title{
Covid-19: Spatial analysis of lethality in France during the first epidemic inception
}

\author{
Marc Souris and Jean-Paul Gonzalez
}

1 The case-fatality rate of a disease in a population is an index of severity of the disease in that population, and of the capacity of the healthcare system to reduce mortality. In principle, this allows to compare the effectiveness of healthcare systems across regions or countries: when population risk factors and reporting systems are identical, casefatality rate evaluation represents an excellent tool for analyzing, understanding and improving the overall performance of the health system, particularly at the level of hospital units. Studying the magnitude of differences in case-fatality rates between units also makes it possible to assess the impact of the quality of the health system on case-fatality.

2 Since the beginning of the Covid-19 epidemic, the case-fatality rate (CFR) of Covid-19 and the differences between countries have been the subject of many questions about national pandemic response policies and patient treatment. Most studies on the lethality of Covid-19 seek to estimate the true lethality of the disease, an issue that has been addressed since the beginning of the epidemic.

The aim of this article is to analyze the effectiveness of the healthcare system in France in the context of the Covid-19 epidemic. This study also discusses the differences and the comparison on case-fatality rates published by the international agency by country (May 2020).

4 The principal objective of this article is to estimate the influence of the healthcare system on lethality by analyzing the spatial variability of the hospital case-fatality rate (confirmed hospitalized cases and hospital deaths) between metropolitan districts in France during the first wave of the epidemic in France (19 March to 28 May). The study focuses on the extent of spatial differences in the case-fatality rate between districts. The other objective is to analyze the case-fatality rate observed in metropolitan France with the one calculated for other countries. 
This study is based on daily hospitalization and death declaration data by district. Since age is a major risk factor for death for Covid-19 patients, all rates were standardized on this factor. In order to estimate whether possible congestion in the healthcare system influenced hospital case-fatality rate, we studied the correlations between hospitalization and hospital lethality. Inpatient severity was estimated using the ICU rate (number of patients admitted in intensive care /number of inpatients). We analyzed also relationship between standardized CFR and healthcare system capacity.

This study shows that the high case-fatality rates observed in France in some districts during the first wave of the Covid-19 epidemic could be linked to two phenomena: on the one hand, to the high level of morbidity in the district, and therefore to the possible tension in the healthcare systems during the acute phase of the epidemic; on the other hand, when the hospitalization rate remained low, to healthcare access in sparsely populated districts.

Fig. A typology combining standardized hospitalization rates $(\mathrm{H})$ and standardized case-fatality rates $(\mathrm{L})$ in five classes. The purple class (High $\mathrm{H}$, high $\mathrm{L}$ ) correspond to the epicenters of the epidemic, is clustered, and include the densely populated areas of lle-de-France. The red class (low $H$, high $L$ ) is geographically dispersed, sparsely populated and mainly located in rural areas.

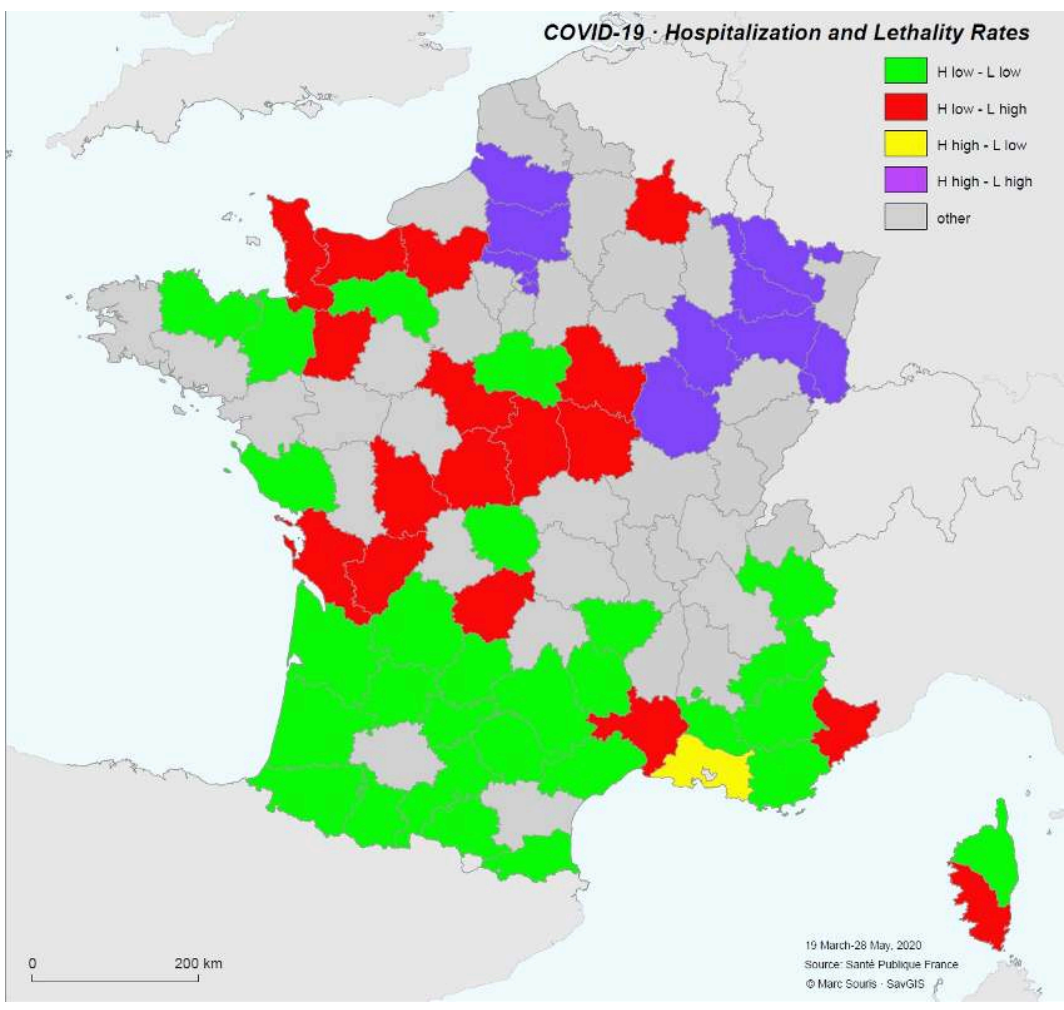

7 Nevertheless, the increase in the standardized case-fatality rate due to exceptional situations during the peak of the epidemic cannot explain the magnitude of the difference observed between the average case-fatality rate in France and those reported for all countries by international organizations or information sites (WHO, Wordometer, etc.). These differences most likely stem from the unequal reporting of cases and deaths depending on the country, and not from patient management. 
INDEX

Keywords: Covid-19, lethality, standardisation, spatial analysis, SLR

\section{AUTHORS}

MARC SOURIS

UMR Unité des Virus Émergents (UVE Aix-Marseille Univ-IRD 190-Inserm 1207-IHU Méditerranée Infection), Marseille 13005 France

\section{JEAN-PAUL GONZALEZ}

School of Medicine, Georgetown University, Department of Microbiology \& Immunology, Washington, DC 20057 USA. Centaurus Biotech LLC 